\title{
Current Pharmacological Approaches to the Therapy of Varicella Zoster Virus Infections
}

\section{A Guide to Treatment}

\author{
Robert Snoeck, Graciela Andrei and Erik De Clercq
}

Rega Institute for Medical Research, Katholieke Universiteit Leuven, Leuven, Belgium

\section{Contents}

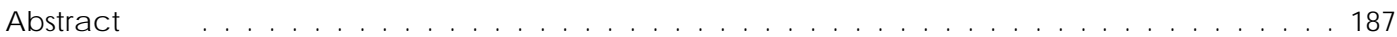

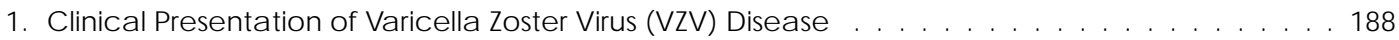

2. Prevention of VZV Infections . . . . . . . . . . . . . . . . . . . . . . . . . . 190

2.1 Passive Immunisation . . . . . . . . . . . . . . . . . . . . . . . . . . . . . . . . 190

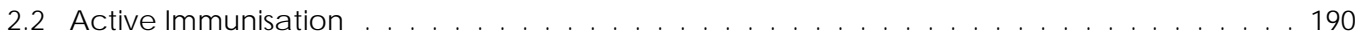

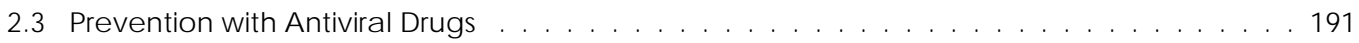

3. Treatment of VZV Infections . . . . . . . . . . . . . . . . . . . . . . . . . . . . 191

3.1 Current Status of Varic ella Chemothera py . . . . . . . . . . . . . . . . . . . . . 192

3.1.1 Immunocompetent Patients . . . . . . . . . . . . . . . . . . . . 192

3.1 .2 Immunocompromised Patients . . . . . . . . . . . . . . . . 193

3.2 Current Status of Herpes Zoster Chemotherapy . . . . . . . . . . . . . . . . . . . 193

3.2.1 Immunocompetent Patients . . . . . . . . . . . . . . . . . . . 193

3.2 .2 Immunocompromised Patients . . . . . . . . . . . . . . . . . . . . 194

3.3 Resistance . . . . . . . . . . . . . . . . . . . . . . . . . . . . . 195

4. Different Drugs Active Aga inst VZV and Their MolecularTargets . . . . . . . . . . . . . . 196

4.1 Thymid ine Kinase (TK) Phosphorylation, Targeted at Viral DNA Polymera se . . . . . . . . 196

4.2 Viral Thymidylate Synthase . . . . . . . . . . . . . . . . . . . . . 198

4.3 Viral Ribonucleotide Reductase . . . . . . . . . . . . . . . . . . . . . . . . 199

4.4 Drugs Not Dependent on Viral TK Phosphorylation

Targeted at Viral DNA Polymerase . . . . . . . . . . . . . . . . . . . . . . . . . . . . 199

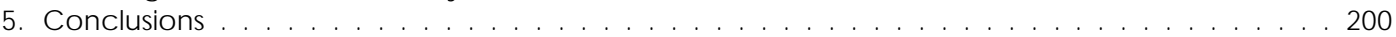

\section{Abstract}

Varicella zoster virus (VZV), a member of the herpesvirus family, is responsible for both primary (varicella, chickenpox) as well as reactivation (zoster, shingles) infections. In immunocompetent patients, the course of varicella is generally benign. For varicella zoster, post-herpetic neuralgia is the most common complication. In immunocompromised patients (particularly those with AIDS), transplant recipients and cancer patients, VZV infections can be life-threatening. For these patients and also for immunocompetent patients at risk such as pregnant women or premature infants, the current treatment of choice is based on either intravenous or oral aciclovir (acyclovir).

The low oral bioavailability of aciclovir, as well as the emergence of drugresistant virus strains, have stimulated efforts towards the development of new 
compounds for the treatment of individuals with VZV infections. Among these new compounds, penciclovir, its oral prodrug form famciclovir and the oral prodrug form of aciclovir (valaciclovir), rank among the most promising. As with aciclovir itself, all of these drugs are dependent on the virus-encoded thymidine kinase (TK) for their intracellular activation (phosphorylation), and, upon conversion to their triphosphate form, they act as inhibitors/alternative substrate of the viral DNA polymerase. Therefore, cross-resistance to these drugs may be expected for those virus mutants that are TK-deficient and thus resistant to aciclovir. Other classes of nucleoside analogues dependent for their phosphorylation on the viral TK that have been pursued for the treatment of VZV infections include sorivudine, brivudine, fialuridine, fiacitabine and netivudine. Among oxetanocins, which are partially dependent on viral TK, lobucavir is now under clinical evaluation. Foscarnet, which does not require any previous metabolism to interact with the viral DNA polymerase, is used in the clinic when TK-deficient VZV mutants emerge during aciclovir treatment. TK-deficient mutants are also sensitive to the acyclic nucleoside phosphonates (i.e. [s]-1-[3-hydroxy-2-phosphonylmethoxypropyl]cytosine; HPMPC); these agents do not depend on the virus-encoded TK for their phosphorylation but depend on cellular enzymes for conversion to their diphosphoryl derivatives which then inhibit viral DNA synthesis.

Vaccination for VZV has now come of age. It is recommended for healthy children, patients with leukaemia, and patients receiving immunosuppressive therapy or those with chronic diseases. The protection induced by the vaccine seems, to some extent, to include zoster and associated neuralgia. Passive immuniatin based on specific immunoglobulins does not effectively prevent VZV infection and is therefore restricted to high risk individuals (i.e. immunocompromised children and pregnant women).

\section{Clinical Presentation of Varicella Zoster Vinus (VZV) Disease}

Varicella zoster virus (VZV) is a member of the herpesvirus family. It is responsible for a primary disease (varicella or chickenpox) as well as recurrent disease (zoster or shingles) following reactivation of the virus in one or more dorsal root ganglia. Mostly, the rash due to varicella infections is a typical feature of the disease and the course of the illness is generally benign, with a low grade fever persisting as long as new lesions continue to appear. The most marked symptom of these infections is pruritus which can last throughout the different stages of the disease. The most frequent complication of varicella infections in the normal host is bacterial superinfection of the skin lesions. ${ }^{[1-4]}$

Varicella pneumonia is the most common serious complication in adults. It is rarely seen in chil- dren. The incidence of varicella pneumonia has varied in different studies from 4.5 up to $50 \% .^{[5-7]}$ Symptoms are often more severe than the physical examination would suggest and $70 \%$ of cases of varicella pneumonia have occurred within the first 3 days of illness. Mortality has ranged from 10 to $40 \%{ }^{[6,8]}$ and fatal cases have been mostly associated with widespread haematogenous dissemination. Fatalities have also occurred due to one single organ failure. ${ }^{[9]}$ Pregnant women are at greater risk of VZV pneumonia than other adults. ${ }^{[7,10-13]}$ More atypical presentations, such as rhabdomyolysis, have also been associated with acute varicella infection. ${ }^{[14]}$

The congenital varicella syndrome was thought to occur after maternal VZV infection only in the first trimester of pregnancy, but current information indicates that the period of risk appears to extend to the first half of pregnancy. ${ }^{[15]}$ If infections 
occur later in pregnancy, malformations are less extensive, sometimes involving only peripheral scars.

About 1 to 5\% of pregnancies exposed early in the gestation to VZV will lead to a congenital varicella syndrome. ${ }^{[13,16,17]}$ The clinical features of the syndrome include scarring of the skin, hypoplasia of the limbs, muscular atrophy, rudimentary digits, cortical atrophy, psychomotoric retardation, chorioretinitis, microcephaly and cataracts. Defects involving the brain and the eye are similar to those seen in congenital infections caused by the rubella virus and cytomegalovirus (CMV) but the other features are quite different. Scars of the skin, usually cicatricial lesions in a dermatomal distribution are a unique feature of the varicella syndrome and indicate that VZV is dermatotropic, even in utero.

While similar fetal abnormalities may follow maternal herpes zoster infection, the congenital syndrome attributable to herpes zoster is exceedingly rare. ${ }^{[18,19]}$ Therefore, it seems that the fetus is in much greater danger following primary than recurrent maternal infection, as is also the case for herpes simplex virus (HSV) or CMV infections. Neonatal varicella is seen in infants without sufficient maternal antibodies who have been contaminated just before or soon after birth. The disease is often widely disseminated with pneumonitis and visceral involvement, ${ }^{[20]}$ and the fatality rate can exceed $30 \% .^{[21]}$

As a neurotropic virus, VZV has also caused encephalitis, most often in children; this is the second most frequent indication for hospitalisations due to varicella infections, after secondary infections. ${ }^{[22]}$ Other neurological complications include Reye's syndrome, transient neurological signs, aseptic meningitis, transverse myelitis, polyneuritis and Guillain-Barré syndrome. The severity of VZV infections in cancer patients, particularly those with haematopoietic or reticuloendothelial malignancies undergoing cytotoxic and/or radiation therapy, is now well demonstrated. [1,2,23-25] $^{-}$

Herpes zoster is common in bone marrow transplant (BMT) patients. The median time of occurrence is 4 to 5 months after transplantation, with almost all cases occurring in the first year. An overall mortality rate of 5 to $10 \%$ has been observed among patients not receiving antiviral treatment, death being the result of progressive disease dissemination with pneumonia. The mortality rate is nearly $30 \%$ in patients presenting with disseminated rash without dermatomal localisation. ${ }^{[26,27]}$ In adult patients undergoing autologous BMT for Hodgkin's disease, prior history of varicella is often associated with the development of herpes zoster in the first 150 days after transplantation. ${ }^{28]}$

VZV infections in patients with HIV may be more prolonged or severe, and their clinical presentation is often unusual. Multidermatomal involvement and hyperkeratotic skin lesions seem to occur specifically in immunocompromised patients. Coalescence of single lesions, haemorrhagic bullae, extensive ulceration with epidermal necrosis and black eschars have also been observed. Isolation of the virus from these lesions has proved difficult. ${ }^{[29-34]}$ VZV infections are also a frequent cause of morbidity and hospitalisation for HIV-1infected children. ${ }^{[35]}$

Herpes zoster occurs in individuals previously infected with VZV. After initial infection, VZV establishes and maintains latency within the dorsal root ganglia until a stimulus leads to its reactivation. Immune senescence, characterised by the decline in $\mathrm{T}$ cells specific for certain microbial antigens with age, is mostly responsible for the increased incidence of zoster in persons over 45 years of age. ${ }^{[36]}$ The complications of herpes zoster are essentially neurological, and postherpetic neuralgia is the greatest cause of acute and chronic morbidity associated with herpes zoster, particularly in the elderly. Other neurological complications include motor neuropathy, particularly in patients with zoster ophthalmicus. ${ }^{[37]}$ Symptomatic meningoencephalitis and myelitis are rare, despite pleocytosis in about $40 \%$ of the cerebrospinal fluid (CSF) samples tested. Nevertheless, in some series of encephalitis without Guillain-Barré syndrome, elevated CSF lymphocyte counts and protein levels were observed in all cases. ${ }^{[38]}$ 
VZV is almost never recovered from the CNS during the acute phase, which tends to support an immunologic pathogenesis. ${ }^{[39-41]} \mathrm{CNS}$ diseases attributed to VZV in immunocompromised patients can appear without skin rash. ${ }^{[42-48]}$ Recently, several authors reported zoster myelitis in both HIVinfected $^{[49-51]}$ and nonimmunocompromised ${ }^{[51]}$ patients. In patients with AIDS, VZV is often associated with acute retinal necrosis, a disease with severe prognosis. ${ }^{[52,53]}$

\section{Prevention of VZV Infections}

Prevention of varicella infections is mostly reserved for immunocompromised patients and is based on both passive and active immunisation. $\mathrm{Pa}-$ tients at risk of contracting severe forms of varicella (who are therefore candidates for a prophylactic action) include patients with leukaemia or Hodgkin's disease or other diseases of the lymphoreticular system, patients with cancer treated with immunosuppressive drugs and BMT patients, irrespective of their own or the donor's serological VZV status. Also, patients with diseases requiring high doses of systemic corticosteroids for a long period, children of mothers who contracted varicella during pregnancy or premature infants of mothers without a history of varicella have to be considered as being at greater risk for the development of a severe varicella infection.

\subsection{Pa ssive Immunisation}

Passive immunisation is based on the use of human immunoglobulin preparations with high titres of antibody to VZV which are obtained from patients recovering from varicella zoster infections. Specific VZV immune globulins should be given preferably not longer than 96 hours after contact with either varicella or herpes zoster. Nevertheless, most of the studies concluded that specific immune globulins do not effectively prevent VZV infection. ${ }^{[54]}$ Even in patients at risk, where the rationale of administering specific immune globulins was not so much to prevent infection but to mitigate the severity of the disease, no clear-cut data have been obtained. ${ }^{[55,56]}$ The use of VZV-specific immune globulins has been restricted to high risk individuals, including immunocompromised children and pregnant women, who have had close exposure to an individual with varicella or herpes zoster. ${ }^{[57-59]}$

\subsection{Active Immunisation}

A live-attenuated varicella vaccine has been obtained starting from the reference strain Oka. ${ }^{59-61]}$ Predisposition for the development of severe varicella is due to impairment of the cell-mediated immune response to VZV, rather than to a defect in humoral immunity. ${ }^{[62,63]}$ The vaccine is highly protective in healthy children, and those that are not fully protected show evidence of partial immunity. ${ }^{[64]}$ Seroconversion in healthy children after 1 dose of vaccine has been about $95 \%$ and persistence of antibodies has been observed in $>90 \%$ for at least 2 years. ${ }^{[64,65]}$ Some data have suggested that antibody- and cell-mediated immune responses to VZV develop in parallel after immunisation. ${ }^{[66]}$

The more robust the antibody response after VZV vaccination, the more likely an individual is to have complete protection from disease in subsequent years. The antibody titres measured 6 weeks after vaccination could be used as a surrogate marker for protection from natural disease. ${ }^{[67]}$ Most breakthrough infections seem to occur in the first few years after vaccination. No virus has ever been grown from these lesions and it has been recently demonstrated that there was no transmission of the live-attenuated vaccine strains to immunocompromised children after immunisation of their sibling. ${ }^{[68]}$

The varicella vaccine is highly protective in children with leukaemia, although a minority of children only achieve partial immunity. The seroconversion rate was $>90 \%$ when the children received a 2-dose vaccination regimen. ${ }^{[69]}$ Thus, the efficacy of the vaccine in children with leukaemia who seroconverted has been similar to that in healthy children. In children with leukaemia, the incidence of adverse effects in the first 6 weeks after immunisation was significantly higher than in healthy children. About 1 month after vaccination, 
$50 \%$ of children have developed rashes and fever, and some of them had to be treated with oral or intravenous aciclovir. It was possible to isolate the viral vaccine strain from the skin lesions. ${ }^{[70-71]}$ After vaccination, patients with leukaemia acquired a long term immunity. In addition, the attack rate of clinical varicella among vaccinees who had again become seronegative and who had household exposures was only $30 \%$, compared with 80 to $90 \%$ that could be expected in varicella-susceptible patients. ${ }^{[70]}$

It has been shown that zoster is less common after vaccination with the varicella vaccine than after natural infection. ${ }^{[66-72]}$ It has also been demonstrated that immunisation of elderly people with the varicella vaccine causes a durable cellmediated immune response to VZV. ${ }^{[73-75]} \mathrm{Also}$, statistically significant increases in varicella antibody titres were observed after immunisation with high doses of live-attenuated or heat-inactivated vaccine in healthy seropositive adults. ${ }^{[76]}$

After VZV infection of the skin, the virus migrates along the nerves to the posterior ganglia, where it persists in a latent form. However, a haematogenous migration of the virus to the ganglia cannot be completely ruled out. VZV has been recovered from the blood of patients with natural varicella, but not from healthy vaccine recipients. Thus, the question arises whether the VZV vaccine strain can cause latent infection. Children with leukaemia do have a higher incidence of zoster than those in a healthy matched population. Therefore, vaccinated children with leukaemia have been followed closely for zoster and compared with children with leukaemia who have had natural varicella. From this surveillance study it appeared that the incidence of zoster was significantly lower in vaccinees than in children with leukaemia with past natural varicella. ${ }^{[72,77]}$ The lower incidence of varicella zoster in the vaccinees could be explained by the fact that the vaccine strain is attenuated. Most likely, the virus may have no access to the sensory ganglia if the skin is not infected. ${ }^{[78]}$

This was confirmed by follow-up studies of children with leukaemia where zoster developed far more frequently in those who had had rash after immunisation than those without rash. ${ }^{[63]}$ A study of vaccination in the elderly showed that the immune response was similar and sustained when that group was compared with 35- to 40-year-old individuals. Age had little effect on the response to the vaccine, but larger doses were associated with longer duration of enhanced immunity. Only 3 out of the 200 patients that were vaccinated developed zoster in the subsequent 4 years. ${ }^{[79,80]}$

In summary, the target groups for vaccination are healthy children older than 12 months, patients with acute leukaemia (total lymphocyte counts $>1200 / \mu \mathrm{l}$ ), patients receiving immunosuppressive therapy who have lymphocyte counts $>1200 / \mu 1$, patients who have to undergo a solid organ transplantation, patients with chronic diseases and people in close contact with immunocompromised patients. The actual recommendations for the administration of the varicella vaccine are as follows: (a) one dose for healthy children between 12 and 18 months of age without a history of VZV infection;

(b) one dose for children between 18 months and 13 years of age that have not been vaccinated yet and do not have a history of VZV infection and;

(c) two doses with an interval of 4 to 8 weeks for healthy teenagers and adults that have not been vaccinated yet and do not have a history of VZV infection. ${ }^{[81,82]}$

\subsection{Prevention with Antiviral Drugs}

In a recent study, aciclovir given orally (40 $\mathrm{mg} / \mathrm{kg} /$ day in 4 divided doses) for 5 days to healthy children susceptible to varicella was shown to prevent or modify the clinical course of varicella. ${ }^{[83]}$ Persistence of protective immunity after postexposure prophylaxis of varicella with oral aciclovir in the family setting was recently demonstrated. ${ }^{[84]}$

\section{Treatment of VZV Infections}

The appearance of new drugs with better bioavailability has considerably changed the landscape of VZV chemotherapy ${ }^{[85-88]}$ (table I). 
Table I. Recommended dosages of currently available drugs in the treatment of varicella zoster virus (VZV) in patients with normal renal function

\begin{tabular}{|c|c|c|c|c|c|c|}
\hline Drug & Formulation & Indication & Patient group & Dose & $\begin{array}{l}\text { Dosage } \\
\text { interval }\end{array}$ & $\begin{array}{l}\text { Treatment } \\
\text { duration (days) }\end{array}$ \\
\hline \multirow{6}{*}{$\begin{array}{l}\text { Aciclovir } \\
\text { (acyclovir) }^{[89]}\end{array}$} & \multirow{4}{*}{$\begin{array}{l}\text { Oral tablets, } \\
\text { capsules and } \\
\text { suspension }\end{array}$} & Treatment of varicella & Adults & $800 \mathrm{mg}$ & 5 times daily & 7 \\
\hline & & (chicken pox) & Children & $20 \mathrm{mg} / \mathrm{kg}(\leq 800 \mathrm{mg})$ & qid & 5 \\
\hline & & $\begin{array}{l}\text { Treatment of herpes } \\
\text { zoster (shingles) }\end{array}$ & Adults & $800 \mathrm{mg}$ & 5 times daily & 7 \\
\hline & & $\begin{array}{l}\text { Management of } \\
\text { severely } \\
\text { immunocompromised } \\
\text { patients }\end{array}$ & $\begin{array}{l}\text { Adults and children } \\
\text { (>2 years) }\end{array}$ & $800 \mathrm{mg}$ & qid & $\geq 6 \mathrm{mo}$ \\
\hline & Intravenous & Treatment of VZV & Adults & $5\left(10^{\mathrm{a}}\right) \mathrm{mg} / \mathrm{kg}$ & every $8 \mathrm{~h}$ & $\geq 5$ \\
\hline & $\begin{array}{l}\text { solution for } \\
\text { infusion }\end{array}$ & infections & Children (3 mo-12y) & $250\left(500^{\mathrm{a}}\right) / \mathrm{mg} / \mathrm{m}^{2}$ & every $8 \mathrm{~h}$ & $\geq 5$ \\
\hline Valaciclovir ${ }^{[90]}$ & Oral tablets & $\begin{array}{l}\text { Treatment of herpes } \\
\text { zoster }\end{array}$ & Adults & $1000 \mathrm{mg}$ & tid & 7 \\
\hline Famciclovir ${ }^{[91]}$ & Oral tablets & $\begin{array}{l}\text { Treatment of herpes } \\
\text { zoster }\end{array}$ & Adults & $250 \mathrm{mg}$ or $500 \mathrm{mg}$ & tid & 7 \\
\hline
\end{tabular}

a In immunocompromised patients.

$\mathbf{m o}=$ months $;$ qid $=$ four times daily; tid $=$ three times daily; $\mathbf{y}=$ years.

\subsection{Current Status of \\ Varic ella Chemotherapy}

\subsubsection{Immunocompetent Patients}

In patients with normal immune status, varicella infections are usually benign and symptomatic treatment most often suffices. This includes closely cropping finger and toe nails, a cleansing bath to prevent secondary bacterial infections and treatment of pruritus and pyrexia. Several clinical studies have been conducted recently to define the clinical place of aciclovir in the treatment of varicella. ${ }^{[92-95]}$ Two studies performed in children from 2 to 12 years of age concluded that oral aciclovir $20 \mathrm{mg} / \mathrm{kg} 4$ times per day for 5 days accelerated cessation of lesion formation, decreased the total number of new lesions formed and lowered the need for antipruritic and analgesic treatment when aciclovir treatment was initiated within 24 hours of disease onset. ${ }^{[92,93]}$ Another study, comparing oral aciclovir with placebo in adults with varicella, confirmed these results. ${ }^{[93]}$ Similar conclusions were obtained in adolescents ${ }^{[94]}$ and adults ${ }^{[95]}$ to whom intravenous aciclovir was administered.

Since uncontrolled studies had shown some efficacy of oral aciclovir in adult varicella infec- tion, ${ }^{[96]}$ a randomised, placebo-controlled trial, using oral aciclovir $800 \mathrm{mg} 5$ times daily for 7 days, was undertaken. ${ }^{[6]}$ This study ascertained that early therapy within 24 hours with aciclovir decreased the time of cutaneous healing (whatever parameter was used), shortened the duration of fever and diminished symptoms. Starting aciclovir treatment within 24 hours after onset of symptoms was of no value in uncomplicated cases of adult varicella.

The use of oral aciclovir in normal and atopic children with varicella infections has been reviewed elsewhere, ${ }^{[97]}$ and recommendations for the use of oral aciclovir have also been published. ${ }^{[98]}$ In addition, intravenous aciclovir may improve the outcome of varicella pneumonia in adults, including pregnant women. ${ }^{[10-12]}$ Aciclovir therapy did not alter the acquisition of long term immunity to VZV. ${ }^{[92]}$ To date, no clinical trials have been conducted with valaciclovir and famciclovir, the prodrugs of aciclovir and penciclovir, respectively, for the treatment of varicella infections in nonimmunocompromised patients. Recently, another nucleoside analogue, sorivudine (B-Vara-U, brovavir, BV-Ara-U, BVAU), which is known to be the most potent inhibitor of VZV in vitro, was compared 
with placebo for the treatment of varicella infections in immunocompetent adults. ${ }^{[99]}$ Given orally once a day at 10 or $40 \mathrm{mg}$, sorivudine shortened the mean time to crusting and cessation of new lesion formation. ${ }^{[100]}$

\subsubsection{Immunocompromised Patients}

Because of the recognised complications of varicella infections in the immunocompromised host, several experimental antiviral drugs have been tried in limited clinical trials. Cytarabine (cytosine arabinoside; Ara-C) and idoxuridine have proven too toxic for systemic use in patients with VZV infections. ${ }^{[101,102]}$ In addition to aciclovir, ${ }^{[89,103]}$ interferon- $\alpha$ and vidarabine also lead to an improvement of varicella and herpes zoster symptoms. Interferon- $\alpha$ (IFN $\alpha$ ) has been used to treat varicella infections in a group of children with cancer. ${ }^{[104,105]}$ Intramuscular IFN $\alpha 0.4$ to $3.5 \times 10^{5}$ $\mathrm{IU} / \mathrm{kg} /$ day for 5 days significantly reduced the duration of lesion formation and visceral dissemination.

The first drug that proved successful in the chemotherapy of varicella in immunocompromised hosts was vidarabine. In a study where vidarabine at $10 \mathrm{mg} / \mathrm{kg} /$ day was compared with placebo, patients receiving vidarabine ceased to form new lesions and fever in these patients abated more rapidly than in patients receiving placebo. The incidence of life-threatening complications was significantly lower in the treated group than in the placebo group, and when therapy was initiated within 72 hours of the disease onset, outcome was beneficially influenced. ${ }^{[106]}$ When aciclovir was used in a similar study, therapy had no effect on cutaneous healing or fever. However, administration of aciclovir did counteract the development of pneumonitis. ${ }^{[107]}$ Improvement in the outcome of varicella in immunocompromised children treated with aciclovir was confirmed in another study. ${ }^{[108]}$ Oral aciclovir $800 \mathrm{mg} 5$ times daily for 7 days proved to be efficacious in 25 immunocompromised children with varicella infections. In only 2 children was oral aciclovir required to be changed to the intravenous formulation. All children recovered from their VZV infection. ${ }^{[109]}$

\subsection{Current Status of Herpes ZosterChemotherapy}

\subsubsection{Immunocompetent Patients}

Intravenous aciclovir in healthy patients with herpes zoster accelerates the rate of cutaneous healing and reduces the severity of acute neuritis, but has no effects on postherpetic neuralgia. ${ }^{[110-112]}$ Oral administration of aciclovir has accelerated the rate of cutaneous healing and reduced the severity of acute neuritis. ${ }^{[113,114]}$ If the therapy was initiated within 48 hours after disease onset, clinical benefits were more evident, particularly in herpes zoster ophthalmicus where the incidence of uveitis and keratitis were reduced as compared with the placebo group. ${ }^{[115]}$ In another study, a topical ophthalmic aciclovir preparation was compared with topical corticosteroids, and fewer relapses of ocular inflammation were noted in the aciclovir group. ${ }^{[116]}$ In a randomised study, oral aciclovir reduced peripheral sensory axonopathy due to ganglion damage and prevented the possibility of spread to anterior roots and spinal motorneurons, thus reducing the incidence of segmental motor neuritis. ${ }^{[117]}$

The major problem with herpes zoster is the development of postherpetic neuralgia. ${ }^{[118]}$ Systemic corticosteroids have been widely used for prevention of postherpetic neuralgia. ${ }^{[119,120]}$ The rationale for their use has been to limit inflammation and subsequent scarring in the dorsal root ganglia, factors that might be responsible for postherpetic neuralgia. However, a controlled study of aciclovir with or without prednisolone in patients with zoster failed to show any benefit. ${ }^{[121]}$ Two recent studies indicated that the addition of corticosteroids to aciclovir accelerated resolution of acute pain but had no effect on long term pain. ${ }^{[122,123]}$ However, in 1 of these studies addition of corticosteroids to aciclovir improved quality of life. ${ }^{[123]}$

The effect of aciclovir on postherpetic neuralgia is rather limited, as has been shown in several studies. ${ }^{[124,125]}$ A meta-analysis from 5 trials of oral aciclovir (800mg per day within 72 hours of rash onset) for the treatment of herpes zoster showed that aciclovir may reduce the incidence of residual 
pain at 6 months by $46 \%$ in immunocompetent adults. ${ }^{[126]}$ Valaciclovir, the prodrug of aciclovir, has been compared with placebo in adult patients with herpes zoster. Valaciclovir 1000mg 3 times daily for 7 days was significantly more effective than placebo in terminating new lesion formation. ${ }^{[90]}$ In a large study in immunocompetent adults, in comparison with aciclovir, valaciclovir $1000 \mathrm{mg}$ 3 times daily for 7 days accelerated the resolution of pain while cutaneous manifestations resolved at similar rates in both groups. ${ }^{[127]}$ Valaciclovir not only proved to be more efficient than aciclovir in promoting healing of lesions, but was also more effective than aciclovir in shortening the duration of postherpetic neuralgia. ${ }^{[128]}$

In a double-blind randomised study, intravenous penciclovir or aciclovir $5 \mathrm{mg} / \mathrm{kg} 3$ times daily for 5 days each, had comparable efficacy in the treatment of immunocompetent patients with herpes zoster. $^{[129]}$

In a prospective double-blind study enrolling 419 patients, famciclovir 500 or $750 \mathrm{mg} 3$ times daily for 7 days, compared with placebo, was effective, well tolerated and decreased the duration of postherpetic neuralgia. ${ }^{[130]}$ The beneficial effect of famciclovir on postherpetic neuralgia was further confirmed by Huse and colleagues. ${ }^{[131]}$ In a randomised, multicentre trial, famciclovir 250, 500 and $750 \mathrm{mg} 3$ times daily was as effective as aciclovir $800 \mathrm{mg} 5$ times daily in healing cutaneous zoster lesions. Time to loss of acute pain was similar in all famciclovir and aciclovir groups. All 3 regimens of famciclovir were associated with a more rapid resolution of zoster-associated pain than in those receiving aciclovir. ${ }^{[132]}$ The safety data analysis of 13 completed clinical studies has demonstrated that famciclovir has a safety profile similar to that of placebo. ${ }^{[133]}$

\subsubsection{Immunocompromised Patients}

Interferon IFN $\alpha$, vidarabine and aciclovir have been shown to be useful in patients at high risk for the development of life-threatening infection due to herpes zoster. IFN $\alpha$ given to patients with herpes zoster and an underlying malignancy resulted in a decrease in vesicle formation and a lowered fre- quency of cutaneous dissemination. ${ }^{[134]}$ Patients treated with IFN $\alpha$ also had a significant decrease in postherpetic neuralgia. Vidarabine was shown to be active against herpes zoster if therapy was begun within 72 hours of onset: vidarabine prevented progression of lesion formation within the dermatome and allowed gradual regression of the lesions in the area involved. ${ }^{[135-137]}$ Vidarabine therapy also resulted in a significant decrease in visceral complications (encephalitis, hepatitis and uveitis) as compared with the placebo group. ${ }^{[136]}$ Like IFN $\alpha$, vidarabine clearly reduced the duration of the chronic pain associated with zoster. ${ }^{[39]}$ This was obtained when vidarabine $10 \mathrm{mg} / \mathrm{kg} /$ day over 12 hours for 7 days was administered. Aciclovir, like vidarabine and IFN $\alpha$, favourably influenced the duration of new lesion formation and virus shedding, lesion healing time and rate of dissemination of lesions to skin and viscera.

Intravenous, but not oral, aciclovir therapy has resulted in plasma concentrations that exceed the concentration required to reduce viral replication by $50 \%\left(\mathrm{IC}_{50}\right)$ for VZV. ${ }^{[138]}$ The oral bioavailability of aciclovir is relatively low $(\leq 20 \%)$. After repeated oral doses of aciclovir 200 or $800 \mathrm{mg}$, mean steady state peak plasma concentrations of 0.6 and $1.6 \mathrm{mg} / \mathrm{L}$ have been reported, respectively, while after intravenous administration of doses of 5 or $10 \mathrm{mg} / \mathrm{kg}$, peak plasma aciclovir concentrations reached 10 and $20 \mathrm{mg} / \mathrm{L}$, respectively. The terminal half-life of aciclovir in plasma is 2 to 3 hours in adults with normal renal function. ${ }^{[103]}$

Aciclovir was first demonstrated to be active against herpes zoster in a placebo-controlled tri$a l,{ }^{[139]}$ where it reduced the frequency of cutaneous dissemination and visceral complications. In those studies where the efficacy of aciclovir and vidarabine were compared in the treatment of herpes zoster in immunocompromised patients, ${ }^{[140,141]}$ aciclovir proved clearly advantageous over vidarabine in terms of cutaneous healing or disease progression. In addition, those patients receiving aciclovir were discharged from hospital more promptly. ${ }^{[142]}$

Brivudine (BVDU, bromovinyldeoxyuridine) and sorivudine have also been the subject of lim- 
ited clinical trials and have proven to be efficacious in the treatment of zoster infections in immunocompromised patients. ${ }^{[143,144]}$ Brivudine has been used successfully in the treatment of progressive outer retinal necrosis. ${ }^{[143]}$ Also, oral brivudine has proven to be as efficacious as, if not more so than, intravenous aciclovir in the treatment of immunocompromised patients. ${ }^{[144]}$

Oral brivudine $7.5 \mathrm{mg} / \mathrm{kg} /$ day administered for 5 days to patients with underlying malignancy and severe herpes zoster has stopped disease progression within 1 day after initiation of treatment. ${ }^{[145]}$ Similar results were obtained in children with cancer (receiving brivudine orally at $15 \mathrm{mg} / \mathrm{kg} /$ day for 5 days $)^{[146]}$ and in immunocompetent adults with herpes zoster. ${ }^{[147,148]}$ As a rule, all patients recovered rapidly from their VZV infection, and in no case was treatment required to be prolonged for more than 5 days. In addition, none of the brivudine-treated patients showed any evidence of drug toxicity in bone marrow, liver, kidney or any other organ. Sorivudine was found clinically efficacious in both immunocompetent ${ }^{[149]}$ and immunocompromised patients, ${ }^{[150,151]}$ who received oral sorivudine 10 or $50 \mathrm{mg} / \mathrm{kg} 3$ times a day. Recently, in a comparative study of sorivudine and aciclovir in the treatment of dermatomal herpes zoster in HIV patients, sorivudine was as effective as aciclovir when the time to the resolution of zoster-associated pain, the frequency of dissemination and the frequency of zoster recurrence were recorded. Administration of sorivudine resulted in accelerated cutaneous healing compared to aciclovir. ${ }^{[152]}$

A serious drug interaction between sorivudine and fluorouracil has been identified. Bromovinyluracil, a metabolite of sorivudine made mainly by bacteria in the gut, is an inhibitor of dihydropyrimidine dehydrogenase, an enzyme required for the metabolism of pyrimidines and pyrimidine derivatives such as fluorouracil. ${ }^{[153]}$ In Japan, death occurred in patients receiving fluorouracil concomitantly with sorivudine. These deaths were attributed to fluorouracil myelotoxicity, resulting from the inhibitory effect of sorivudine (via bromovinyluracil) on fluorouracil degradation. ${ }^{[154]}$
Accordingly, it is unlikely that sorivudine will be developed further for commercial use.

\subsection{Resistance}

Recently, several case reports have appeared on the emergence, following long term aciclovir therapy, of aciclovir-resistant VZV strains in patients with AIDS. ${ }^{[46,155-158]}$ That Cole and Balfour Jr ${ }^{[159]}$ could not detect aciclovir-resistant VZV strains in immunocompromised patients after treatment with aciclovir is probably due to the short period (10 days) during which these patients were treated with the drug.

Mutations at the level of the VZV thymidine kinase (TK) are responsible for development of VZV resistance to those drugs that depend on the viral TK for their phosphorylation. ${ }^{[46,160-163]}$ It was demonstrated that aciclovir-resistant VZV is 3- to 20-fold more sensitive to arabinosyl nucleoside analogues than the parent virus. ${ }^{[164]}$ Talarico et al. ${ }^{[165]}$ as well as Boivin et al. ${ }^{[166]}$ analysed the TK gene from aciclovir-resistant VZV strains isolated from AIDS patients. They found a non-sense mutation introducing a terminator codon, thus resulting in the expression of a truncated protein. Previously, a TK deletion was described that was 873 nucleotides long, located in the coding region of the TK gene in a VZV strain isolated from the CSF of an AIDS patient with meningoradiculoneuritis. ${ }^{[46]}$ The mutated TK protein was 51 amino acids long and comprised the 13 aminoterminal amino acids linked to the 38 carboxyterminal amino acids of the wild type protein. Most of the ATP-binding site and the entire nucleoside binding site (proposed by Talarico et al. ${ }^{[165]}$ ) were missing in this truncated protein which, consequently, was completely inactive. ${ }^{[46]}$

There is only little evidence for resistance due to mutations located at the level of the VZV DNA polymerase although suggestive evidence for such alterations stems from the increased $\mathrm{IC}_{50}$ of the virus for foscarnet. ${ }^{[155]}$ Five cases of aciclovirresistant VZV infections treated with foscarnet have been reported, ${ }^{[167]}$ where the clinical responses were not predicted by the in vitro drug 
susceptibility; healing was observed despite resistance to foscarnet and clinical failure was observed despite susceptibility to foscarnet. This discrepancy could at least be partially explained by variations in the pharmacokinetics of foscarnet, particularly the plasma drug concentrations. ${ }^{[168]}$

This is also true with regard to foscarnet concentrations within the CSF. In 2 studies, the concentrations of foscarnet in the CSF of patients with AIDS were recorded. According to Raffi et al., ${ }^{[169]}$ foscarnet penetrates well into the CSF and even better into inflammatory CSF, while Hengge et al. ${ }^{[170]}$ found no correlation between the concentrations of foscarnet in the CSF and the integrity of the blood-brain barrier. In both studies, foscarnet concentrations in the CSF were sufficient to recommend the use of the drug for the treatment of herpesviral encephalitis in AIDS patients. In vitro foscarnet resistance was shown to correlate with absence of clinical response in an AIDS patient with multidermatomal zoster. ${ }^{[171]}$

\section{Different Drugs Active Against VZV and Their Molecular Targets}

\subsection{Thymidine Kinase (TK) Phosphorylation, Targeted at Viral DNA Polymerase}

Most of the compounds that have been pursued for the treatment of VZV infections are nucleoside analogues requiring phosphorylation by the viral TK. The reference molecule for all these compounds is aciclovir. ${ }^{[89,103,172]}$ Aciclovir is converted by the virus-encoded TK to its monophosphate which is then converted to the di- and triphosphate forms by cellular enzymes, resulting in a 40- to 100-fold increase in aciclovir-triphosphate (aciclovir-triphosphate) in infected cells, as compared to uninfected cells. Aciclovir-TP inhibits viral DNA synthesis by competing with deoxyguanosine triphosphate as substrate for the viral DNA polymerase. ${ }^{[173,174]}$ Aciclovir-TP acts as a chain terminator. ${ }^{[175,176]}$ However, since the oral bioavailability of aciclovir is relatively low and variable (between 15 and 30\%), ${ }^{[177]}$ prodrugs of aciclovir have been developed.
The L-valyl ester valaciclovir (VACV) is the prodrug of aciclovir. VACV is well absorbed and quickly converted to aciclovir, thus increasing the bioavailability of aciclovir by 3 - to 5 -fold. The increased bioavailability of aciclovir from VACV may be explained by absorption of the prodrug via a stereospecific transporter followed by its rapid and efficient conversion to aciclovir, presumably via a VACV hydrolase. ${ }^{[178]}$ VACV may be expected to exhibit a similar safety profile as aciclovir itself.

Aciclovir has been reported to have little if any toxicity. The renal dysfunction reported in some cases in patients treated with large doses of aciclovir ${ }^{[179,180]}$ is usually reversible and could be avoided by infusing aciclovir slowly in association with good hydration. Oral aciclovir has not been associated with renal dysfunction. ${ }^{[181]}$ Intravenous administration of aciclovir has been associated with some disturbances at the CNS level. ${ }^{[182,183]}$

Recently, another guanosine analogue, penciclovir, was found to exhibit in cell culture potent activity against both reference strains and clinical isolates of HSV and Epstein-Barr virus. ${ }^{[91,184,185]}$ Penciclovir is highly selective against herpesviruses, because it is phosphorylated, and hence activated, only in herpesvirus-infected cells. ${ }^{[186]}$ The viral TK seems to play a key role in the activation of the molecule, since penciclovir is not active against mutant HSV strains that are deficient in the expression of their TK. ${ }^{[184]}$ In VZV-infected cells, the rate of formation of penciclovir-TP increases as the infection proceeds, but this rate is about 10 -fold less than in cells infected with either HSV-1 or HSV-2. However, the intracellular concentration of penciclovir-TP was at least 30 -fold higher than that of aciclovir-TP under the same conditions. ${ }^{[187]}$

Penciclovir-TP is a less powerful inhibitor of HSV-1 DNA polymerase and VZV DNA polymerase than aciclovir-TP [inhibition constant (Ki) value 100-fold greater for penciclovir-TP than for aciclovir-TP]. Thus, the high concentrations of penciclovir-TP compensate for its diminished affinity for the DNA polymerase, which means that 
in standard plaque reduction assays aciclovir and penciclovir afford similar antiviral activity.

Penciclovir-TP is a competitive inhibitor of HSV-1 and HSV-2 DNA polymerase with respect to the natural substrate deoxyguanosine triphosphate (dGTP). In conditions where aciclovir-TP is clearly acting as a chain terminator, penciclovir-TP does allow limited DNA chain elongation. ${ }^{[185]}$ In addition, penciclovir-TP is a poorer substrate for incorporation into DNA than aciclovir-TP. Penciclovir has been shown to be active against DNA polymerase-based virus mutants resistant to aciclovir, suggesting that the interaction at the level of the enzyme is different for the triphosphates of aciclovir and penciclovir. ${ }^{[185]}$ Also, penciclovir-TP has a longer intracellular half-life than aciclovirTP. The half-life of penciclovir-TP in cells infected with HSV-1, HSV-2 or VZV was 10,20 or 7.2 hours, respectively; for aciclovir-TP the half-life was 0.7 and 1.0 hour in HSV-1- or HSV-2-infected cells, respectively. In VZV-infected cells, the aciclovir-TP concentrations were under the detection limit. ${ }^{[186,187]}$

Penciclovir is poorly absorbed when given orally to rodents and humans, and even in mice oral absorption of penciclovir is less than for aciclovir. ${ }^{[188]}$ Therefore, various derivatives (particularly esters) of penciclovir have been synthesised in attempts to increase its oral bioavailability. Famciclovir, the diacetyl ester of 6-deoxy-penciclovir, has emerged as the best candidate. ${ }^{[189]}$ After oral administration in rats, famciclovir is rapidly absorbed, and taking the sum of all the metabolites the time needed to reach the maximum concentration in blood is about 15 to 20 minutes. Similar results were obtained in human volunteers. ${ }^{[190]}$ Further studies are needed to assess the comparative usefulness of famciclovir (or penciclovir) relative to that of aciclovir ${ }^{[191,192]}$ or valaciclovir.

Among the nucleoside analogues that have been pursued (albeit on a limited scale) for the treatment of VZV infections, the most potent inhibitors of in vitro $\mathrm{VZV}$ replication that have ever been described are brivudine and sorivudine.
Sorivudine and brivudine inhibit in vitro VZV replication at an $\mathrm{IC}_{50}$ of approximately 0.001 $\mathrm{mg} / \mathrm{L}$, while for aciclovir in similar experimental conditions the $\mathrm{IC}_{50}$ is about $4 \mathrm{mg} / \mathrm{L}$. Sorivudineresistant VZV strains selected in vitro were shown to have a decreased viral TK activity. ${ }^{[193]}$

The selective antiviral action of brivudine and sorivudine depends primarily on their phosphorylation by the virus-induced TK. Upon further conversion of the 5'-mono- or diphosphates of the pyrimidine 2'-deoxynucleoside analogues by cellular kinases to the corresponding 5'-triphosphates, the latter may inhibit the DNA polymerase reaction by direct competition with the natural substrate deoxythymidine triphosphate (dTT). ${ }^{\text {194] }}$

Incorporation of brivudine into DNA does not cause premature termination of chain elongation, suggesting that brivudine is incorporated via internucleotide linkage. The incorporation of brivudine into viral DNA leads to a single-strand DNA breakage. When incorporated into synthetic DNA, brivudine reduces the DNA template activity for RNA synthesis. Thus, incorporation of brivudine into DNA may result in both selective degradation of the DNA as well as inadequate mRNA transcription. In contrast with aciclovir, both brivudine and sorivudine have good oral bioavailability. Pharmacokinetic analysis for sorivudine revealed that the elimination half-life has varied from 5 to about 8 hours, with a statistically significant greater halflife in the elderly as compared with young volunteers. Serial measurements of trough serum concentrations showed that sorivudine does not accumulate upon repeated administration. In addition, the trough concentration at 24 hours after a single oral dose was still above the $\mathrm{IC}_{50}$, suggesting that a once-daily dosage regimen may be appropriate for the treatment of VZV infections.

Fluorinated nucleoside analogues (e.g. fialuridine) have also proved effective against a number of herpesviruses including CMV, HSV and VZV. Fiacitabine has shown good activity in vitro against VZV in 3 different cell lines. ${ }^{[195]}$ In vivo, in the simian varicella virus model using African green monkeys fialuridine was less potent (when 
given orally) than its 5-methylated counterpart 1( 2 -deoxy-1-fluoro $\beta$-1-arabinofuranosyl-5-methyuracil (FMAU). ${ }^{[196]}$ The activity of fialuridine was similar to that of brivudine. ${ }^{[197]}$ In immunosuppressed patients with herpes zoster, fiacitabine was considered superior in efficacy to vidarabine. ${ }^{[198]}$

Of the 5-alkynyl-substituted pyrimidine analogues, 2'-deoxy-5-ethynyluridine proved active against VZV but also too toxic to the host (MRC-5) cells, while netivudine (882C) proved to be a selective inhibitor of $\mathrm{VZV}$ replication with an $\mathrm{IC}_{50}$ ranging from 0.17 to $1.07 \mathrm{mg} / \mathrm{L} .{ }^{[199]}$ No activity could be detected against other herpesviruses. Netivudine is dependent on the VZV-encoded TK for its antiviral activity. The compound is phosphorylated to the mono- and diphosphate form by the viral enzyme. The triphosphate of netivudine inhibits the VZV DNA polymerase. The compound retains activity against some $\mathrm{TK}$-altered substrate aciclovir-resistant clinical isolates of VZV and it is also active against laboratory-selected DNA polymerase-based VZV mutants. ${ }^{\text {[200] }}$

Pharmacokinetic studies with netivudine in humans showed a relatively long half-life (12 to $14 \mathrm{~h}$ ) in the plasma. Drug concentrations in the plasma stayed well above the $\mathrm{IC}_{50}$ for at least 24 hours after a single $50 \mathrm{mg}$ oral dose. ${ }^{[201]}$ The oral bioavailability of a $200 \mathrm{mg}$ dose of netivudine was $21.1 \%$ in the young and $24.6 \%$ in the elderly. Higher plasma concentrations in the elderly are explained by reduced renal clearance and a trend to higher bioavailability. ${ }^{[202]}$ Initial clinical studies in elderly patients with localised herpes zoster also suggested a therapeutic benefit with respect to rash healing and pain, ${ }^{[203]}$ but further development of the compound has been suspended by findings of toxicity after long term administration of netivudine to rodents.

Other classes of nucleoside analogues depending for their phosphorylation on the viral TK have been synthesised. Methoxypurine arabinoside (AraM) has been described as a selective and potent inhibitor of VZV in vitro ${ }^{[204]}$ and shows efficacy similar to that of aciclovir in hairless guinea pigs. ${ }^{[205]}$ From a series of seven 6-alkoxypurine arabinosides, methoxypurine arabinoside was the most efficient substrate for the VZV-encoded TK as well as the most potent anti-VZV agent. In vitro, methoxypurine arabinoside was almost 10 -fold more active against VZV replication than aciclovir. The antiviral spectrum of the 6-alkylaminopurine nucleosides appeared to be limited to VZV, the 6-methylaminopurine and the 6-dimethylaminopurine derivatives being the most potent VZV inhibitors from this group. These compounds are not detectably phosphorylated by either adenosine kinase or 2'-deoxycytidine kinase. Instead, there was a clear correlation between their in vitro antiviral potency and their substrate affinity for the VZVencoded TK. ${ }^{[206]}$

Oxetanocins (OXT) may be regarded as cyclobutyl nucleoside analogues in which the carbocyclic carbon has been replaced by an oxygen. OXTadenine, OXT-guanine and OXT-2-aminoadenine proved active against TK-expressing and TKdeficient strains of $\mathrm{VZV} .^{[207]}$ The guanosine derivative lobucavir is now under clinical evaluation for the treatment of both VZV and HBV infections. A-73209 (1[2'R,3'R,4'5]-3',4'-bis-(hydroxymethyl)2'-oxetanyl-5-methyl uracil) belongs to the oxetanocin family. A-73209 is 100-fold more potent than aciclovir against TK-positive strains of VZV. Activity against TK-deficient VZV strains is much lower than against TK-positive VZV strains. A-73209 has been reported to cross the blood-brain barrier following oral administration. ${ }^{[208]}$

\subsection{Viral Thymidylate Synthase}

VZV encodes a thymidylate synthase (TS) that catalyses the conversion of deoxyuridylate (dUMP) to thymidylate (dTMP). Although it has been shown that brivudine, upon its conversion to brivudine monophosphate by the viral TK, can inhibit the virus-induced TS, ${ }^{[209]}$ this by no means proves that the mode of its anti-VZV action is due to inhibition of the VZV-encoded TS. In fact, recent results have suggested that the VZV-encoded TS is not essential for viral replication in cell culture. [210] Other antiherpes compounds such as sorivudine, 
aciclovir, ganciclovir or vidarabine do not inhibit TS activity in VZV-infected cells. ${ }^{\text {[209] }}$

\subsection{Viral Ribonuc leotide Reducta se}

HSV encodes a specific ribonucleotide reductase. This enzyme is responsible for the reduction of the ribonucleotides to the corresponding deoxyribonucleotides and can be considered as a target for antiviral chemotherapy. Recently, a ribonucleotide reductase was partially purified from cells infected with VZV. A-1110U [2-acetylpyridine-5[(dimethyl-amino)thiocarbonyl]thiocarbonohydr azone], which is a potent inhibitor of the ribonucleotide reductase induced by HSV and VZV, was shown to potentiate the activity of aciclovir in vitro. ${ }^{[211]}$ The 2-acetylpyridine 5-[(2-chloroanilino)thiocarbonyl]thiocarbonohydrazone (348U87) was shown to inhibit both VZV and HSV ribonucleotide reductase, and inactivate the viral ribonucleotide reductase faster than A-1110U. In addition, $348 \mathrm{U} 87$ has a more favourable toxicological profile than A-1110U. ${ }^{[212]}$

\subsection{Drugs Not Dependent on \\ Vira ITK Phosphorylation Targeted at Viral DNA Polymerase}

Vidarabine has been extensively investigated in clinical trials as described above. It is no longer the drug of choice for the treatment of VZV infections, mainly because of its relatively low activity, rapid degradation (by deamination) and poor aqueous solubility which necessitates the infusion of large amounts of liquid.

Foscarnet has been used clinically against VZV infections, particularly when resistant viruses appeared under aciclovir treatment, mainly in AIDS patients. The main disadvantage of foscarnet is that it can only be given as an intravenous infusion because of its poor bioavailability. No metabolites of foscarnet have been detected. Sequestration into bone may be responsible for the long terminal phase half-life ( 88 hours) while the first and the second elimination half-lives are 0.5 to 1.4 hours and 3.3 to 6.8 hours, respectively. ${ }^{[213]}$ The most frequent dose-limiting adverse effect of foscarnet therapy is a 2- to 3-fold increase in serum creatinine level in about $45 \%$ of the patients. This is due to acute tubular necrosis which tends to be reversible upon foscarnet withdrawal. Reversible hypercalcaemia and hyperphosphataemia occur in over $66 \%$ of foscarnet recipients, although symptomatic hypercalcaemia has been also observed. Foscarnet also leads to anaemia in 20 to $50 \%$ of patients treated, and penile ulceration has been observed. ${ }^{[213]}$

We have previously described a new class of compounds, namely acyclic nucleoside phosphonates, ${ }^{[214-222]}$ which contain a phosphorus-carbon linkage that resists hydrolysis by cellular esterases. These compounds fall into two categories: phosphonylmethoxyethyl (PME) derivatives, [i.e. 9-(2-phosphonylmethoxy-ethyl)adenine; adefovir (PMEA $)^{[217]}$ and 9-(2-phosphonylmethoxyethyl)diaminopurine; PMEDAP], ${ }^{[223]}$ that are active against both retro- and herpesviruses, and 3-hydroxy2-phosphonylmethoxypropyl (HPMP) derivatives, [i.e. (S)-9-(3-hydroxy-2-phosphonylmethoxypropyl)adenine; HPMPA], ${ }^{[213,214,217]}$ ) which are active against a broad range of DNA viruses including herpesviruses (HSV, VZV, CMV, Epstein-Barr) but also poxviruses (vaccinia virus), iridoviruses (African swine fever virus), hepadnaviruses (hepatitis $\mathrm{B}$ virus) and adenoviruses. The prototype compound HPMPA can be regarded as the hybridisation of two previously described antiviral entities, the (S)-9-(2,3-dihydroxypropyl)adenine (DHPA), which has a broad spectrum antiviral activity against several RNA and DNA viruses, and foscarnet, which is active against herpes-, hepadnaand retroviruses.

Owing to the presence of the phosphonate group, the PME and HPMP derivatives do not need to be phosphorylated by the virus-encoded TK which explains why they are active against TKdeficient strains of HSV and VZV ${ }^{[46,215,224]}$ and DNA viruses like CMV that do not encode for such viral TK. ${ }^{[216,225]}$ In the case of HPMPA, the active derivative is HPMPA diphosphate (HPMPApp) which acts at the DNA polymerase level as a competitive inhibitor with respect to the natural substrate deoxyATP. ${ }^{[226,227]}$ HPMPApp can also be 
incorporated internally into the DNA chain. HPMPC is assumed to act in a similar fashion as HPMPA. ${ }^{[228]}$ In addition to HPMPC monophosphate (HPMPCp) and HPMPC diphosphate (HPMPCpp), the HPMPCp-choline adduct has been isolated as a major metabolite of HPMPC, with a very long intracellular half-life (48 hours). HPMPCp-choline could act as an intracellular reservoir from which the drug is slowly released. ${ }^{[27,228]}$ The phosphonate derivatives also show a long-lasting antiviral response in vivo, ${ }^{[229,230]}$ which seems to be related to their long half-life.

\section{Conclusions}

Vaccination for VZV has now come of age and since the protection induced by the vaccine seems, to some extent, to include zoster and the herewith associated neuralgia, one might consider VZV vaccination in children. Vaccination of immunocompromised children, particularly those with malignancies, should be recommended because of the high morbidity of VZV infection in such patients.

Two new antiviral drugs derived from aciclovir or penciclovir, respectively, have emerged during the last few years. They are characterised by an improved oral bioavailability. The first is valaciclovir, the L-valyl ester of aciclovir, which retains the same activity and safety profile as the mother compound. The second is famciclovir, the oral derivative of penciclovir. Both compounds are active against HSV and VZV, and famciclovir has also been pursued for the treatment of hepatitis B. In addition to valaciclovir and famciclovir, brivudine and sorivudine have proved efficacious in the treatment of VZV infections, and brivudine is currently the subject of a large clinical trial for the treatment of herpes zoster in immunocompetent individuals.

The possible emergence of drug-resistant VZV strains should be taken into account when using new antiviral drugs. For those drug-resistant viruses that emerge under the pressure of aciclovir and related drugs, foscarnet remains an appropriate alternative. Nevertheless, foscarnet-resistant strains as well as patients progressing despite sensitivity of the virus to the drugs have both been described.
Therefore, acyclic nucleoside phosphonate analogues, particularly cidofovir, may acquire an important place in the armamentarium of anti-VZV drugs. An adequate strategy to prevent emergence of virus-drug resistance may be based on the alternating use of the appropriate anti-VZV drugs, particularly in patients with AIDS who need long term prophylaxis for relapsing VZV disease.

\section{Acknowledgements}

The authors would like to thank C. Callebaut for fine editorial help.

\section{References}

1. Weller TH. Varicella and herpes zoster: changing concepts of the natural history, control, and importance of a not-so-benign virus (2 Pt 1). N Engl J Med 1983; 309: 1362-8

2. Weller TH. Varicella and herpes zoster. Changing concepts of the natural history, control, and importance of a not-so-benign virus (2 Pt 2). N Engl J Med 1983; 309: 1434-40

3. Gilden DH, Mahalingam R, Dueland AN, et al. Herpes zoster: pathogenesis and latency. In: Melnick JL, editor. Progress in Medical Virology. Vol. 39. Karger: Basel, 1992: 19-75

4. Arvin AM. Varicella-zoster virus. Clin Microbiol Rev 1996; 9: 361-81

5. Weber DM, Pellechia JA. Varicella pneumonia. JAMA 1965; 192: $572-3$

6. Wallace MR, Bowler WA, Murray NB, et al. Treatment of adult varicella with oral acyclovir: a randomized, placebo-controlled trial. Ann Intern Med 1992; 117: 358-63

7. Hockberger RS, Rothstein RJ. Varicella pneumonia in adults: a spectrum of disease. Ann Emerg Med 1986; 15: 931-4

8. Triebwasser JH, Harris RE, Bryant RE, et al. Varicella pneumonia in adults. Medicine 1967; 46: 409-21

9. Nikkels AF, Delvenne P, Sadzot-Delvaux C, et al. Distribution of varicella zoster virus and herpes simplex virus in disseminated fatal infections. J Clin Pathol 1996; 49: 243-8

10. Haake DA, Zakowski PC, Haake DL, et al. Early treatment with acyclovir for varicella pneumonia in otherwise healthy adults: retrospective controlled study and review. Rev Infect Dis 1990; 12: 788-97

11. Lotshaw RR, Keegan JM, Gordon HR. Parenteral and oral acyclovir for management of varicella pneumonia in pregnancy: a case report with review of literature. W V Med J 1991; 87: 204-6

12. Smego Jr RA, Asperilla MO. Use of acyclovir for varicella pneumonia during pregnancy. Obstet Gynecol 1991; 78: 1112-6

13. Clements DA, Katz SL. Varicella in a susceptible pregnant woman. In: Remington JS, Swartz MN, editors. Current clinical topics in infectious diseases. Boston (MA): Blackwell Scientific Publications, 1993: 123-30

14. Pratt RD, Bradley JS, Loubert C, et al. Rhabdomyolysis associated with acute varicella infection. Clin Infect Dis 1995; 20: 450-3

15. Enders G, Miller E, Cradock-Watson J, et al. Consequences of varicella and herpes zoster in pregnancy: prospective study of 1739 cases. Lancet 1994; 343: 1548-51 
16. Katz VL, Kuller JA, McMahon MJ, et al. Varicella during pregnancy: maternal and fetal effects. J Med 1995; 163: 446-50

17. Paryani SG, Arvin AM. Intrauterine infection with varicellazoster virus after maternal varicella. N Engl J Med 1986; 314 : 1542-6

18. Gershon A. Chickenpox, measles, and mumps. In: Remington JS, Klein JO, editors. Infectious diseases of the fetus and newborn infant. 3rd ed. Philadelphia (PA): WB Saunders, 1990: 395-445

19. Gershon AA. Varicella-zoster virus: prospects for control. Adv Pediatr Infect Dis 1995; 10: 93-124

20. Brunell PA. Varicella in pregnancy, the fetus, and the newborn: problems in management. J Infect Dis 1992; 166 Suppl 1: S42-7

21. Brunell PA. Fetal and neonatal varicella-zoster infections. Semin Perinatal 1983; 7: 47-56

22. Elliott KJ. Other neurological complications of herpes zoster and their management. Ann Neurol 1994; 35 Suppl: S57-61

23. Schimpff S, Serpick A, Stoler B, et al. Varicella-zoster infection in patients with cancer. Ann Intern Med 1972; 76: 241-54

24. Goffinet DR, Glatstein EJ, Merigan TC. Herpes zoster-varicella infections and lymphoma. Ann Intern Med 1972; 76: 235-40

25. Mazur MH, Dolin R. Herpes zoster at the NIH: a 20-year experience. Am J Med 1978; 65: 738-44

26. Taylor CE, Sviland L, Pearson ADJ, et al. Virus infections in bone marrow transplant recipients: a three-year prospective study. J Clin Pathol 1990; 43: 633-7

27. Meyers JD. Infection in recipients of bone marrow transplants. In: Remington JS, Schwartz MN, editors. Current clinical topics in infectious diseases. New York: McGraw-Hill Book Co., 1985: 261-92

28. Christiansen NP, Haake RJ, Hurd DD. Early herpes zoster infection in adult patients with Hodgkin's disease undergoing autologous bone marrow transplant. Bone Marrow Transplant 1991; 7: 435-7

29. Tappero JW, Perkins BA, Wenger JD, et al. Cutaneous manifestations of opportunistic infections in patients infected with human immunodeficiency virus. Clin Microbiol Rev 1995; 8: 440-50

30. Cockerell CJ. Human immunodeficiency virus infection and the skin: a crucial interface. Arch Intern Med 1991; 151: 1295-303

31. Cohen PR, Beltrani VP, Grossman ME. Disseminated herpes zoster in patients with human immunodeficiency virus infection. JAMA 1988; 84: 1076-80

32. Liebovitz E, Kaul A, Rigaud M, et al. Chronic varicella zoster in a child infected with human immunodeficiency virus: case report and review of the literature. Cutis 1992; 49: 27-31

33. Nelson JA, Ghazal P, Wiley CA. Role of opportunistic viral infections in AIDS. AIDS 1990; 4: 1-10

34. Quinnan Jr GV, Masur H, Rook AH, et al. Herpesvirus infections in the acquired immune deficiency syndrome. JAMA 1984; 252: 72-7

35. von Siedlein L, Gillette SG, Bryson Y, et al. Frequent recurrence and persistence of varicella-zoster virus infections in children infected with human immunodeficiency virus type 1 . J Pediatr 1996; 128: 52-7

36. Weksler ME. Immune senescence. Ann Neurol 1994; 35 Suppl.: S35-7

37. McPherson RE. Herpes zoster opthalmicus and the immunocompromised host: a case report and review. J Am Optom Assoc 1997; 68: 527-38
38. Jemsek J, Greenberg SB, Taber L, et al. Herpes zoster-associated encephalitis: clinicopathologic report of 12 cases and review of the literature. Medicine 1983; 62: 81-97

39. Straus SE, Ostrove JM, Inchausp G, et al. Varicella-zoster virus infections: biology, natural history, treatment, and prevention. Ann Intern Med 1988; 108: 221-37

40. Griffin DE. Therapy of viral infections of the central nervous system. Antiviral Res 1991; 15: 1-10

41. Gelb LD. Varicella-zoster virus. In: Fields BN, Knipe DM, editors. Virology. New York: Raven Press, 1990: 2011-54

42. Ryder JW, Croen K, Kleinschmidt-DeMasters BK, et al. Progressive encephalitis three months after resolution of cutaneous zoster in a patient with AIDS. Ann Neurol 1986; 19: 182-8

43. Dueland AN, Devlin M, Martin JR, et al. Fatal varicella-zoster virus meningoradiculitis without skin involvement. Ann Neurol 1991; 29: 569-72

44. Gilden DH, Dueland AN, Devlin ME, et al. Varicella-zoster virus reactivation without rash. J Infect Dis 1992; $166 \mathrm{Suppl}$ 1: $\mathrm{S} 30-4$

45. Heller HM, Carnevale NT, Steigbigel RT. Varicella zoster virus transverse myelitis without cutaneous rash. Am J Med 1990; 88: $550-1$

46. Snoeck R, Gérard M, Sadzot-Delvaux C, et al. Meningoradiculoneuritis due to acyclovir-resistant varicella-zoster virus in an AIDS patient. J Med Virol 1994; 42: 338-47

47. Mouligner A, Pialoux G, Dega H, et al. Brain stem encephalitis due to varicella-zoster virus in a patient with AIDS. 1995 Clin Infect Dis 20: 1378-80

48. Poscher ME. Successful treatment of varicella zoster virus meningoencephalitis in patients with AIDS: report of four cases and review. AIDS 1994; 8: 1115-7

49. de Silva SM, Mark AS, Gilden DH, et al. Zoster myelitis: improvement with antiviral therapy in two cases. Neurology 1996; 47: 929-31

50. Lionnet F, Pulik M, Genet P, et al. Myelitis due to varicellazoster virus in two patients with AIDS: successful treatment with acyclovir. Clin Infect Dis 1996; 22: 138-40

51. Gilden DH, Beinlich BR, Rubinstein EM, et al. Varicella-zoster virus myelitis: an expanding spectrum. Neurology 1994; 44: 1818-23

52. Batisse M, Eliaszewicz M, Zazoun L, et al. Acute retinal necrosis in the course of AIDS: study of 26 cases. AIDS 1996; 10: 55-60

53. Figueroa MS, Garabito I, Gutierrez C, et al. Famciclovir for the treatment of acute retinal necrosis (ARN) syndrome. Am J Ophthalmol 1997; 123: 255-7

54. Arvin AM. Varicella-zoster virus. In: Fields BN, Knipe DM, Howley PM, et al., editors. Field's virology. 3rd ed. Philadelphia (PA): Lippincott-Raven, 1996: 2547-85

55. Brunell PA, Ross A, Miller LH, et al. Prevention of varicella by zoster immune globulin. N Engl J Med 1969; 280: 1191-4

56. Gershon AA, Steinberg S, Brunell PA. Zoster immune globulin: a further assessment. N Engl J Med 1974; 290: 243-5

57. Centers for Disease Control. Varicella zoster immune globulin for the prevention of chickenpox: recommendations of the immunizations practices advisory committee. Ann Intern Med 1984; 100: 859-65

58. Zaia JA, Levin MJ, Preblud SR, et al. Evaluation of varicellazoster immune globulin: protection of immunosuppressed children after household exposure to varicella. J Infect Dis 1983; 147: 737-43

59. Prevention of varicella: recommendations of the Advisory Committee on Immunization Practices (ACIP). MMWR 1996; 45: $1-36$ 
60. Gershon AA. Varicella vaccine: its past, present and future. Pediatr Infect Dis J 1995; 14: 742-4

61. Takahashi M, Otsuka T, Okuno Y, et al. Live vaccine used to prevent the spread of varicella in children in hospital. Lancet 1974; II: 1288-90

62. Feldman S, Lott L. Varicella in children with cancer: impact of antiviral therapy and prophylaxis. Pediatrics 1987; 80: 465-72

63. Hardy IB, Gershon A, Steinberg S, et al. The incidence of zoster after immunization with live attenuated varicella vaccine: a study in children with leukemia. N Engl J Med 1991; 325: 1545-50

64. Kuter BJ, Weibel RE, Guess HA, et al. Oka/Merck varicella vaccine in healthy children: final report of a 2-year efficacy study and 7-year follow-up studies. Vaccine 1991; 9: 642-7

65. Asano Y, Nagai T, Miyata T, et al. Long-term protective immunity of recipients of the Oka strain of live varicella vaccine. Pediatrics 1985; 75: 667-71

66. Hayward A, Villanueba E, Cosyns M, et al. Varicella-zoster virus (VZV)-specific cytotoxicity after immunization of nonimmmune adults with Oka strain attenuated VZV vaccine. J Infect Dis 1992; 166: 260-4

67. White CJ, Kuter BJ, Ngai A, et al. Modified cases of chickenpox after varicella vaccination: correlation of protection with antibody response. Pediatr Infect Dis J 1992; 11: 19-23

68. Diaz PS, Au D, Smith S, et al. Lack of transmission of the live attenuated varicella vaccine virus to immunocompromised children after immunization of their siblings. Pediatrics 1991; 87: 166-70

69. Gershon AA. Human immune responses to live attenuated varicella vaccine. Rev Infect Dis 1991; 13, Suppl 11: S957-9

70. Gershon AA, Steinberg S, NIAID Collaborative Varicella Vaccine Study Group. Persistence of immunity to varicella in children with leukemia immunized with live attenuated varicella vaccine. N Engl J Med 1989; 320: 892-7

71. Tsolia M, Gershon A, Steinberg S, et al. Live attenuated varicella vaccine: evidence that the virus is attenuated and the importance of skin lesions in transmission of varicella-zoster virus. J Pediatr 1990; 116: 184-9

72. Brunell PA, Taylor-Wiedeman J, Geiser CF, et al. Risk of herpes zoster in children with leukemia: varicella vaccine compared with history of chickenpox. Pediatrics 1986; 77: 53-6

73. Berger R, Luescher D, Just M. Enhancement of varicellazoster-specific immune response in the elderly by boosting with varicella vaccine [letter]. J Infect Dis 1984; 149: 647

74. Hayward A, Levin M, Wolf W, et al. Varicella-zoster virusspecific immunity after herpes zoster. J Infect Dis 1991; 163: 873-5

75. Takahashi M, Iketani T, Sasada K, et al. Immunization of the elderly and patients with collagen vascular diseases with live varicella vaccine and use of varicella skin antigen. J Infect Dis 1992; 166 Suppl. 1: S58-62

76. Sperber SJ, Smith BV, Hayden FG. Serologic response and reactogenicity to booster immunization of healthy seropositive adults with live or inactivated varicella vaccine. Antiviral Res 1992; 17: 213-22

77. Lawrence R, Gershon A, Holzman R, et al. The risk of zoster after varicella vaccination in children with leukemia. $\mathrm{N}$ Engl J Med 1988; 318: 543-8

78. Gershon AA, LaRussa P, Hardy I, et al. Varicella vaccine: the American experience. J Infect Dis 1992; 166 Suppl. 1: S63-8

79. Levin MJ, Murray M, Rotbart HA, et al. Immune response of elderly individuals to a live-attenuated varicella vaccine. J Infect Dis 1992; 166: 258-9
80. Levin MJ, Murray M, Zerbe CO, et al. Immune responses of elderly persons 4 years after receiving a live-attenuated vaccine. J Infect Dis 1994; 170: 522-6

81. Committee on Infectious Diseases. Recommendations for the use of live attenuated varicella vaccines. Pediatrics 1995; 95: 791-6

82. ACG Task Force on Adult Immunization and Infectious Disease Society of America. Guide for adult immunisation. 3rd ed. Philadelphia (PA): American College of Physicians, 1994

83. Lin TY, Huang YC, Ning HC, et al. Oral acyclovir prophylaxis of varicella after intimate contact. Pediatr Infect Dis J 1997; 16: $1162-5$

84. Yoshikawa T, Suga S, Kozawa T, et al. Persistence of protective immunity after postexposure prophylaxis of varicella with oral aciclovir in the family setting. Arch Dis Child 1998; 78: 61-3

85. Easterbrook P, Wood MJ. Successors to acyclovir. J Antimicrob Chemother 1994; 34: 307-11

86. Cunningham AL, Dwyer DE. Advances and controversies in the antiviral therapy of herpes zoster. Eur J Clin Microbiol Infect Dis 1996; 15: 273-5

87. Alrabiah FA, Sacks SL. New antiherpesvirus agents: their targets and therapeutic potential. Drugs 1996; 52: 17-32

88. Nikkels AF, Piérard GE. Recognition and treatment of shingles. Drugs 1994; 48: 528-48

89. Wagstaff AJ, Faulds D, Goa KL. Aciclovir: a reappraisal of its antiviral activity, pharmacokinetics properties and therapeutic efficacy. Drugs 1994; 47: 153-205

90. Perry CM, Faulds D. Valaciclovir: a review of its antiviral activity, pharmacokinetic properties and therapeutic efficacy in herpesvirus infections. Drugs 1996; 52: 754-72

91. Perry CM, Wagstaff AJ. Famciclovir: a review of its pharmacological properties and therapeutic efficacy in herpesvirus infections. Drugs 1995; 50: 398-415

92. Balfour Jr HH, Kelly JM, Suarez CS, et al. Acyclovir treatment of varicella in otherwise healthy children. J Pediatr 1990; 116: 633-9

93. Dunkle LM, Arvin AM, Whitley RJ, et al. A controlled trial of acyclovir for chickenpox in normal children. N Engl J Med 1991; 325: 1539-44

94. Balfour Jr HH, Dunkle LM, Feder HM, et al. Acyclovir treatment of varicella in otherwise healthy adolescents. J Pediatr 1993; 120: 627-33

95. Al-Nakib W, Al-Kandari S, El-Khalik DM, et al. A randomized controlled study of intravenous acyclovir (Zovirax) against placebo in adults with chickenpox. J Infect 1983; 6: 49-56

96. Feder HM. Treatment of adult chickenpox with oral acyclovir. Arch Intern Med 1990; 150: 2061-5

97. Rothe MJ, Feder Jr HM, Grant-Kels JM. Oral acyclovir therapy for varicella and zoster infections in pediatric and pregnant patients: a brief review. Pediatr Dermatol 1991; 8: 236-42

98. Committee on Infectious Diseases. The use of oral acyclovir in otherwise healthy children with varicella. Pediatrics 1993; 91 : 674-6

99. Wallace MR, Chamberlin CJ, Sawyer MH, et al. Treatment of adult varicella with sorivudine: a randomized, placebo-controlled trial. J Infect Dis 1996; 174: 249-55

100. Whitley RJ. Sorivudine: a potent inhibitor of varicella zoster virus replication. Adv Exp Med Biol 1996; 394: 41-4

101. Stevens DA, Jordan GW, Waddall TP, et al. Adverse effects of cytosine arabinoside on disseminated zoster in a controlled trial. N Engl J Med 1973; 289: 873-8 
102. Chow AW, Forester JH, Hryniuk W. Cytosine arabinoside therapy for herpesvirus infections. Antimicrob Agents Chemother 1970; 10: 214-7

103. Whitley RJ, Gnann Jr JW. Acyclovir: a decade later. N Engl J Med 1992; 327: 782-9

104. Arvin A, Feldman S, Merigan TC. Human leukocyte interferon in the treatment of varicella in children with cancer: a preliminary controlled trial. Antimicrob Agents Chemother 1978; 13: 605-7

105. Arvin AM, Kushner JH, Feldman S, et al. Human leukocyte interferon for treatment of varicella in children with cancer. N Engl J Med 1982; 306: 761-5

106. Whitley RJ, Hilty M, Haynes R, et al. Vidarabine therapy of varicella in immunosuppressed patients. J Pediatr 1982; 1: 125-31

107. Prober DG, Kirk LE, Keeney RE. Acyclovir therapy of chickenpox in immunosuppressed children - a collaborative study. J Pediatr 1982; 101: 622-5

108. Nyerges G, Meszner Z, Gyarmati E, et al. Acyclovir prevents dissemination of varicella in immunocompromised children. J Infect Dis 1988; 157: 309-13

109. Meszner Z, Nyerges G, Bell AR. Oral acyclovir to prevent dissemination of varicella in immunocompromised children. $\mathrm{J}$ Infect 1993; 26: 9-15

110. Bean B, Braun C, Balfour Jr HH. Acyclovir therapy for acute herpes zoster. Lancet 1982; II: 118-21

111. Peterslund NA, Seyer-Hansen K, Ipen J, et al. Acyclovir in herpes zoster. Lancet 1981; II: 827-30

112. McGill J, MacDonald DR, Fall C, et al. Intravenous acyclovir in acute herpes zoster infection. J Infect Dis 1983; 6: 157-61

113. Wood MJ, Ogan PH, McKendrick MW, et al. Efficacy of oral acyclovir treatment of acute herpes zoster. Am J Med 1988; 85 Suppl. 2A: 79-83

114. Morton P, Thomson AN. Oral acyclovir in the treatment of herpes zoster in general practice. N Z Med J 1989; 102: 93-5

115. Cobo LM, Foulks GN, Liesegang T. Oral acyclovir in the treatment of acute herpes zoster ophthalmicus. Ophthalmology 1986; 93: 763-70

116. McGill J, Chapman C. A comparison of topical acyclovir with steroids in the treatment of herpes zoster keratouveitis. Br J Ophthalmol 1983; 67: 746-50

117. Mondelli M, Romano C, Passero S, et al. Effects of acyclovir on sensory axonal neuropathy, segmental motor paresis and postherpetic neuralgia in herpes zoster patients. Eur Neurol 1996; 36: 288-92

118. Bowsher D. The management of postherpetic neuralgia. Postgrad Med J 1997; 73: 623-9

119. Eaglstein WH, Katz R, Brown JA. The effects of early corticosteroid therapy on the skin eruption and pain of herpes zoster. JAMA 1970; 211: 1681-3

120. Elliott FA. Treatment of herpes zoster with high doses of prednisone. Lancet 1964; II: 610-1

121. Esmann V, Kroon S, Peterslund NA. Prednisolone does not prevent postherpetic neuralgia. Lancet 1987; II: 126-9

122. Wood MJ, Johnson RW, McKendrick MW, et al. A randomized trial of acyclovir for 7 days or 21 days with and without prednisolone for treatment of acute herpes zoster. N Engl J Med 1994; 330: 896-900

123. Whitley RJ, Weiss H, Gnann JR JW, et al. Acyclovir with and without prednisone for the treatment of herpes zoster. Ann Intern Med 1996; 125: 376-83

124. Huff JC, Drucker JL, Clemmer A, et al. Effect of oral acyclovir on pain resolution in herpes zoster: a reanalysis. J Med Virol 1993; Suppl. 1: 93-6
125. Choo PW, Galil K, Donahue JG, et al. Risk factors for postherpetic neuralgia. Arch Intern Med 1997; 157: 1217-24

126. Jackson JL, Gibbons R, Meyer G, et al. The effect of treating herpes zoster with oral acyclovir in preventing postherpetic neuralgia: a meta-analysis. Arch Intern Med 1997; 157: 909-12

127. Beutner KR, Friedman DJ, Porszpaniak C, et al. Valaciclovir compared with acyclovir for improved therapy for herpes zoster in immunocompetent adults. Antimicrob Agents Chemother 1995; 39: 1546-53

128. Herne K, Cirelli R, Lee P, et al. Antiviral therapy of acute herpes zoster in older patients. Drugs Aging 1996; 8: 97-112

129. Duschet P, Auer-Grumbach P, Gschnait F. Efficacy and safety of penciclovir (PCV) in the treatment of patients with herpes zoster (HZ): a double-blind, randomised, acyclovir (ACV)controlled study [abstract no. 1708]. Abstracts of the 32nd Interscience Conference on Antimicrobial Agents and Chemotherapy, 1992 Oct 11-14; Anaheim (CA)

130. Tyring S, Barbarash RA, Nahlik JE, et al. Famciclovir for the treatment of acute herpes zoster: effects on acute disease and postherpetic neuralgia: a randomized, double-blind, placebocontrolled trial. Ann Intern Med 1995; 123: 89-96

131. Huse DM, Schainbaum S, Kirsch AJ, et al. Economic evaluation of famciclovir in reducing the duration of postherpetic neuralgia. Am J Health Syst Pharm 1997; 54: 1180-4

132. Degreef H, Famciclovir herpes zoster clinical study group. Famciclovir, a new oral antiherpes drug: results of the first controlled clinical study demonstrating its efficacy and safety in the treatment of uncomplicated herpes zoster in immunocompetent patients. Int J Antimicrob Agents 1994; 4: 241-6

133. Saltzman R, Jurewicz R, Boon R. Safety of famciclovir in patients with herpes zoster and genital herpes. Antimicrob Agents Chemother 1994; 38: 2454-7

134. Merigan TC, Rand KH, Pollard RB. Human leukocyte interferon for the treatment of herpes zoster in patients with cancer. N Engl J Med 1978; 298: 981-7

135. Whitley RJ, Ch'ien LT, Dolin R, et al. Adenine arabinoside therapy of herpes zoster in the immunosuppressed. N Engl J Med 1976; 294: 1193-9

136. Whitley RJ, Soong SJ, Dolin R, et al. Early vidarabine therapy to control the complications of herpes zoster in immunosuppressed patients. N Engl J Med 1982; 307: 971-5

137. Johnson MT, Luby JP, Buchanan RA, et al. Treatment of varicella-zoster virus infections with adenine arabinoside. J Infect Dis 1975; 131: 225-9

138. Biron KK, Elion GB. In vitro susceptibility of varicella-zoster to acyclovir. Antimicrob Agents Chemother 1980; 18: 443-7

139. Balfour Jr HH, Bean B, Laskin OL, et al. Acyclovir halts progression of herpes zoster in immunocompromised patients. $\mathrm{N}$ Engl J Med 1983; 308: 1448-53

140. Shepp D, Dandliker PS, Meyers JD. Treatment of varicellazoster virus in severely immunocompromised patients: a randomized comparison of acyclovir and vidarabine. N Engl J Med 1986; 314: 208-12

141. Whitley RJ. Therapeutic approaches to varicella-zoster virus infections. J Infect Dis 1992; 166 Suppl. 1: S51-7

142. Whitley RJ, Gnann Jr JW, Hinthorn D, et al. Disseminated herpes zoster in the immunocompromised host: a comparative trial of acyclovir and vidarabine. J Infect Dis 1992; 165: 4505

143. Dullaert H, Maudgal PC, Leys A, et al. Bromovinyldeoxyuridine treatment of outer retinal necrosis due to varicella-zoster virus: a case report. Bull Soc Belge Ophtalmol 1997; 262: 107-13 
144. Wutzler P, De Clercq E, Wutke K, et al. Oral brivudin $v$ s intravenous acyclovir in the treatment of herpes zoster in immunocompromised patients: a randomized double-blind trial. J Med Virol 1995; 46: 252-7

145. Wildiers J, De Clercq E. Oral (E)-5-(2-bromovinyl)-2'-deoxyuridine treatment of severe herpes zoster in cancer patients. Eur J Cancer Clin Oncol 1984; 4: 471-6

146. Benoit Y, Laureys G, Delbeke M-J, et al. Oral BVDU treatment of varicella and zoster in children with cancer. Eur J Pediatr 1985; 143: 198-202

147. Maudgal PC, Dralands L, Lamberts L, et al. Preliminary results of oral BVDU treatment of herpes zoster ophthalmicus. Bull Soc Belge Ophthal 1981; 193: 49-56

148. De Clercq E, Degreef H, Wildiers J, et al. Oral (E)-5-(2Bromovinyl)-2'-deoxyuridine in severe herpes zoster [letter]. BMJ 1980; 281: 1178

149. Niimura M. Adouble-blind clinical study in patients with herpes zoster to establish YN-72 (Brovavir) dose. Adv Exp Med Biol 1990; 278: 267-75

150. Niimura M, Nishikawa T, Ogawa H, et al. YN-72 dose-finding double-blind clinical study in patients with herpes zoster: the study of clinical efficacy. Clin Virol 1990; 18: 115-26

151. Hiraoka A, Masaoka T, Nagai K, et al. Clinical effect of BVaraU on varicella-zoster virus infection in immunocompromised patients with haematological malignancies. J Antimicrob Chemother 1991; 27: 361-7

152. Gnann JR JW, Crumpacker CS, Lalezari JP, et al. Sorivudine versus acyclovir for treatment of dermatomal herpes zoster in human immunodeficiency virus-infected patients: results from a randomized, controlled clinical trial. Antimicrob Agents Chemother 1998; 42: 1139-45

153. Desgranges C, Razaka G, De Clercq E, et al. Effect of (E)-5-(2bromovinyl)uracil on the catabolism and antitumor activity of 5-fluorouracil in rats and leukemic mice. Cancer Res 1986; 46: 1094-101

154. Okuda H, Nishiyama T, Ogura K, et al. Lethal drug interactions of sorivudine, a new antiviral drug, with oral 5-fluorouracil prodrugs. Drug Metab Dispos 1997; 25: 270-3

155. Pahwa S, Biron K, Lim W, et al. Continuous varicella-zoster infection associated with acyclovir resistance in a child with AIDS. JAMA 1988; 260: 2879-82

156. Linnemann Jr CC, Biron KK, Hoppenjans WG, et al. Emergence of acyclovir-resistant varicella zoster virus in an AIDS patient on prolonged acyclovir therapy. AIDS 1990; 4: 577-9

157. Jacobson MA, Berger TG, Fikrig S, et al. Acyclovir-resistant varicella zoster virus infection after chronic oral acyclovir therapy in patients with the acquired immunodeficiency syndrome (AIDS). Ann Intern Med 1990; 112: 187-91

158. Smith KJ, Kahlter C, Davis C, et al. Acyclovir-resistant varicella zoster responsive to foscarnet. Arch Dermatol 1991; 127: 1069-71

159. Cole NL, Balfour Jr HH. Varicella-zoster does not become more resistant to acyclovir during therapy. J Infect Dis 1986; 153: 605-8

160. Mori H, Shiraki K, Kato T, et al. Molecular analysis of the thymidine kinase gene of thymidine kinase-deficient mutants of varicella-zoster virus. Intervirology 1988; 29: 301-10

161. Lacey SF, Suzutani T, Powell KL, et al. Analysis of mutations in the thymidine kinase genes of drug-resistant varicellazoster virus populations using the polymerase chain reaction. J Gen Virol 1991; 72: 623-30

162. Suzutani T, Lacey SF, Powell KL, et al. Random mutagenesis of the thymidine kinase gene of varicella-zoster virus. J Virol 1992; 66: 2118-24
163. Roberts GB, Fyfe JA, Gaillard RK, et al. Mutant varicella-zoster virus thymidine kinase: correlation of clinical resistance and enzyme impairment. J Virol 1991; 65: 6407-13

164. Shiroaki K, Namazue J, Okuno T, et al. Novel sensitivity of acyclovir-resistant varicella-zoster virus to anti-herpetic drugs. Antiviral Chem Chemother 1990; 1: 373-5

165. Talarico CL, Phelps WC, Biron KK. Analysis of the thymidine kinase genes from acyclovir-resistant mutants of varicellazoster virus isolated from patients with AIDS. J Virol 1993; 67: $1024-33$

166. Boivin G, Edelman CK, Pedneault L, et al. Phenotypic and genotypic characterization of acyclovir-resistant varicellazoster viruses isolated from persons with AIDS. J Infect Dis 1994; 170: 68-75

167. Safrin S, Berger TG, Gilson I, et al. Foscarnet therapy in five patients with AIDS and acyclovir-resistant varicella-zoster virus infection. Ann Intern Med 1991; 115: 19-21

168. Lietman PS. Clinical pharmacology: foscarnet. Am J Med 1992; 92 Suppl. 2A: 85-115

169. Raffi F, Taburet AM, Ghaleh B, et al. Penetration of foscarnet into cerebrospinal fluid of AIDS patients. Antimicrob Agents Chemother 1993; 37: 1777-80

170. Hengge UR, Brockmeyer NH, Malessa R, et al. Foscarnet penetrates the blood-brain barrier: rationale for therapy of cytomegalovirus encephalitis. Antimicrob Agents Chemother 1993; 37: 1010-4

171. Fillet A-M, Visse B, Caumes E, et al. Foscarnet-resistant multidermatomal zoster in a patient with AIDS. Clin Infect Dis 1995; $21: 1348-9$

172. Elion GB, Furman PA, Fyfe JA, et al. Selectivity of action of an antiherpetic agent, 9-(2-hydroxyethoxymethyl)guanine. Proc Natl Acad Sci U S A 1977; 74: 5716-20

173. Fyfe JA, Keller PM, Furman PA, et al. Thymidine kinase from herpes simplex virus phosphorylates the new antiviral compound, 9-(2-hydroxyethoxymethyl)guanine. J Biol Chem 1978; 253: 8721-7

174. Derse D, Cheng Y-C, Furman PA, et al. Inhibition of purified human and herpes simplex virus-induced DNA polymerases by 9-(2-hydroxyethoxymethyl)guanine triphosphate: effects on primer-template function. J Biol Chem 1981; 256: 11447-51

175. Furman PA, St Clair MH, Spector T. Acyclovir triphosphate is a suicide inactivator of the herpes simplex virus DNA polymerase. J Biol Chem 1984; 259: 9575-9

176. Reardon JE, Spector T. Herpes simplex virus type 1 DNA polymerase: mechanism of inhibition by acyclovir triphosphate. $\mathrm{J}$ Biol Chem 1989; 264: 7405-11

177. de Miranda P, Blum MR. Pharmacokinetics of acyclovir after intravenous and oral administration. J Antimicrob Chemother 1983; 12 Suppl. B: 29-37

178. Weller S, Blum M, Doulette M, et al. Pharmacokinetics of the acyclovir prodrug, valaciclovir, after escalating single- and multiple-dose administration to normal volunteers. Clin Pharmcol Ther 1993; 54: 595-605

179. Spiegal DM, Lau K. Acute renal failure and coma secondary to acyclovir therapy. JAMA 1986; 255: 1882-3

180. Bianchetti MG, Roduit C, Oetliker OH. Acyclovir-induced renal failure: course and risk factors. Pediatr Nephrol 1991; 5: 238-9

181. Huff JC, Bean B, Balfour Jr HH, et al. Therapy of herpes zoster with oral acyclovir. Am J Med 1988; 85 Suppl. 2A: 84-9

182. Cohen SMZ, Minkove JA, Zebley JW, et al. Severe but reversible neurotoxicity from acyclovir [letter]. Ann Intern Med 1984; 100: 920 
183. Wade JC, Meyers JD. Neurologic symptoms associated with parenteral acyclovir treatment after marrow transplantation. Ann Intern Med 1983; 98: 921-5

184. Boyd MR, Bacon TH, Sutton D, et al. Antiherpesvirus activity of 9-(4-hydroxy-3-hydroxymethylbut-1-yl)guanine (BRL 39123) in cell culture. Antimicrob Agents Chemother 1987; 31: $1238-42$

185. Vere Hodge RA. Famciclovir and penciclovir: the mode of action of famciclovir including its conversion to penciclovir. Antiviral Chem Chemother 1993; 4: 67-84

186. Vere Hodge RA, Perkins RM. Mode of action of 9-(4-hydroxy3-hydroxymethylbut-1-yl)guanine (BRL 39123) against herpes simplex virus in MRC-5 cells. Antimicrob Agents Chemother 1989; 33: 223-9

187. Earnshaw DL, Bacon TH, Darlison SJ, et al. Penciclovir: mode of antiviral action of penciclovir in MRC-5 cells infected with herpes simplex virus (HSV-1), HSV-2, and varicella-zoster virus. Antimicrob Agents Chemother 1992; 36: 2747-57

188. Boyd MR, Bacon TH, Sutton D. Antiherpesvirus activity of 9-(4hydroxy-3-hydroxymethylbut-1-yl)guanine (BRL 39123) in animals. Antimicrob Agents Chemother 1988; 32: 358-63

189. Vere Hodge RA, Sutton D, Boyd MR, et al. Selection of an oral prodrug (BRL 42810; famciclovir) for the antiherpesvirus agent BRL 39123 [9-(4-hydroxy-3-hydroxymethylbut-1-yl)guanine; penciclovir]. Antimicrob Agents Chemother 1989; 33: 1765-73

190. Winton CF, Fowles SE, Vere Hodge RA, et al. Assay of famciclovir and its metabolites, including the antiherpes agent penciclovir, in plasma and urine of rat, dog and man. In: Reid E, Wilson ID, editors. Analysis of drugs and metabolites. Cambridge: Royal Society of Chemists, 1990: 163-71

191. Littler E, Ertl P, Emmerson A, et al. Comparative anti-viral effects of acyclovir and penciclovir (famciclovir) [abstract no. 14]. Antiviral Res 1993; Suppl. 1: 53

192. Crumpacker C. The pharmacological profile of famciclovir. Semin Dermatol 1996; 15 Suppl. 1: 14-26

193. Sakuma T. Strains of varicella-zoster virus resistant to $1-\beta-D-$ arabinofuranosyl-E-5-(2-bromovinyl)uracil. Antimicrob Agents Chemother 1984; 25: 742-6

194. Yokota T, Konno K, Shigeta S, et al. Comparative inhibition of DNA polymerases from varicella zoster virus (TK+ and TK-) strains by (E)-5-(2-bromovinyl)-2'-deoxyuridine 5'-triphosphate. Mol Pharmacol 1984; 26: 376-80

195. Machida H, Ijichi K, Ohta A, et al. Antiviral potencies of BVaraU and related nucleoside analogues against varicellazoster virus in different cell lines. Microbiol Immunol 1990; 34: $959-65$

196. Soike KF, Cantrell C, Gerone PJ. Activity of 1-(2'-deoxy-2'fluoro- $\beta$-D-arabinofuranosyl)-5-iodouracil against simian varicella virus infections in African green monkeys. Antimicrob Agents Chemother 1986; 29: 20-5

197. Soike KF, Gibson S, Gerone PJ. Inhibition of simian varicella virus infection of African green monkeys by (E)-5-(2bromovinyl)-2'-deoxyuridine (BVDU). Antiviral Res 1981; 1: 325-37

198. Leyland-Jones B, Donnelly H, Groshen S, et al. 2'-Fluoro-5iodoarabinosylcytosine, a new potent antiviral agent: efficacy in immunosuppressed individuals with herpes zoster. J Infect Dis 1986; 154: 430-6

199. Rahim SG, Trivedi N, Pether MJ, et al. 5-Alkynyl pyrimidine nucleosides as potent selective inhibitors of varicella zoster virus (VZV) [abstract no. 179]. Antiviral Res 1993; 20 Suppl. 1: 139
200. Talarico CL, Stanat SC, Rahim SG, et al. In vitro antiviral activity of 1-(beta-D-arabinofuranosyl)-5-(1-propynyl)uracil against varicella zoster virus [abstract no. 128]. Antiviral Res 1993; Suppl. 1: 113

201. Fillastre JP, Godin M, Legallicier B, et al. Pharmacokinetics of netivudine, a potent anti-varicella zoster virus drug, in patients with renal impairment. J Antimicrob Chemother 1996; 37: 965-74

202. Peck RW, Wootton R, Lee DR, et al. The bioavailability and disposition of 1-( $\beta$-D-arabinofuranosyl)-5-(1-propynyl)uracil (882C87), a potent, new anti-varicella zoster virus agent. Br J Clin Pharmacol 1995; 39: 143-9

203. Wood MJ, McKendrick MW, Mandal B, et al. An open study of $882 \mathrm{C}$ to investigate clinical potential, pharmacokinetics and safety in patients with herpes zoster [abstract no. P26-6]. Abstracts of the Ninth International Congress of Virology; 1993 Aug 8-13; Glasgow, 204

204. Averett DR, Koszalka GW, Fyfe JA, et al. 6-Methoxypurine arabinoside as a selective and potent inhibitor of varicellazoster virus. Antimicrob Agents Chemother 1991; 35: 851-7

205. Myers MG, Stanberry LR. Drug testing for activity against varicella-zoster virus in hairless guinea pigs. Antiviral Res 1991; 15: 341-4

206. Koszalka GW, Averett DR, Fyfe JA et al. 6-N-Substituted derivatives of adenine arabinoside as selective inhibitors of varicella-zoster virus. Antimicrob Agents Chemother 1991; 35: 1437-43

207. Sakuma T, Saijo M, Suzutani T, et al. Antiviral activity of oxetanocins against varicella-zoster virus. Antimicrob Agents Chemother 1991; 35: 1512-4

208. Alder J, Mitten M, Norbeck D, et al. Efficacy of A-73209, a potent orally active agent against VZV and HSV infections. Antiviral Res 1994; 23: 93-105

209. Yokota T, Konno K, Shigeta S. Inhibition of thymidylate synthetase activity induced in varicella-zoster virus infected cells by (E)-5-(2-bromovinyl)-2'-deoxyuridine [abstract 135]. Antiviral Res 1993; 20 Suppl. 1: 117

210. Cohen JI, Seidel KE. Generation of varicella-zoster virus (VZV) and viral mutants from cosmid DNAs: VZV thymidylate synthetase is not essential for replication in vitro. Proc Natl Acad Sci U S A 1993; 90: 7376-80

211. Spector T, Harrington JA, Morrison Jr RW, et al. 2-Acetylpyridine 5-[(dimethylamino)-thiocarbonyl]thiocarbonohydrazone (A1110U), a potent inactivator of ribonucleotide reductases of herpes simplex and varicella-zoster viruses and a potentiator of acyclovir. Proc Natl Acad Sci U S A 1989; 86: 1051-5

212. Spector T, Harrington JA, Porter DJT. Herpes and human ribonucleotide reductases. Biochem Pharmacol 1991; 42: 91-6

213. Chrisp P, Clissold SP. Foscarnet: a review of its antiviral activity, pharmacokinetic properties and therapeutic use in immunocompromised patients with cytomegalovirus retinitis. Drugs 1991; 41: 104-29

214. De Clercq E, Holý A, Rosenberg I, et al. A novel selective broad-spectrum anti-DNA virus agent. Nature 1986; 323: 464-7

215. De Clercq E, Sakuma T, Baba M, et al. Antiviral activity of phosphonylmethoxyalkyl derivatives of purine and pyrimidines. Antiviral Res 1987; 8: 261-72

216. Snoeck R, Sakuma T, De Clercq E, et al. (S)-1-(3-hydroxy-2phosphonylmethoxy-propyl)cytosine, a potent and selective inhibitor of human cytomegalovirus replication. Antimicrob Agents Chemother 1988; 32: 1839-44

217. Balzarini J, Naesens L, Herdewijn P et al. Marked in vivo antiretrovirus activity of 9-(2-phosphonylmethoxyethyl)adenine, 
a selective anti-human immunodeficiency virus agent. Proc Natl Acad Sci U S A 1989; 86: 332-6

218. Baba M, Konno K, Shigeta S, et al. In vitro activity of (S)-9-(3hydroxy-2-phosphonylmethoxypropyl)adenine against newly isolated clinical varicella-zoster virus strains. Eur J Clin Microbiol 1987; 6: 158-60

219. De Clercq E. Therapeutic potential of HPMPC as an antiviral drug. Rev Med Virol 1993; 3: 85-96

220. Naesens L, Snoeck R, Andrei G, et al. HPMPC (cidofovir), PMEA (adefovir) and related acyclic nucleoside phosphonate analogues: a review of their pharmacology and clinical potential in the treatment of viral infections. Antiviral Chem Chemother 1997; 8: 1-23

221. Hitchcock MJM, Jaffe HS, Martin JC, et al. Cidofovir, a new agent with potent anti-herpesvirus activity. Antiviral Chem Chemother 1996; 7: 115-27

222. Safrin S, Cherrington J, Jaffe HS. Clinical use of cidofovir. Rev Med Virol 1997; 7: 145-56

223. Naesens L, Balzarini J, Rosenberg I, et al. 9-(2-phosphonylmethoxyethyl)-2,6-diaminopurine (PMEDAP): a novel agent with anti-human immunodeficiency virus activity in vitro and potent anti-Moloney murine sarcoma virus activity in vitro. Eur J Clin Microbiol Infect Dis 1989; 8: 1043-7

224. Snoeck R, Schols D, Sadzot-Delvaux C, et al. Flow cytometric method for the detection of gpI antigens of varicella zoster virus and evaluation of anti-VZV agents. J Virol Methods 1992; 38: 243-54

225. Neyts J, Snoeck R, Schols D, et al. Selective inhibition of human cytomegalovirus DNA synthesis by (S)-1-(3-hydroxy-2-phosphonylmethoxypropyl)cytosine [(S)-HPMPC] and 9-(1,3-di- hydroxy-2-propoxymethyl)guanine (DHPG). Virology 1990; 179: $41-50$

226. Votruba I, Bernaerts R, Sakuma T, et al. Intracellular phosphorylation of broad-spectrum anti-DNA virus agent (S)-9-(3-hydroxy-2-phosphonylmethoxypropyl)adenine and inhibition of viral DNA synthesis. Mol Pharmacol 1987; 32: 524-9

227. Ho H-T, Woods KL, Bronson KL, et al. Intracellular metabolism of the antiherpes agent (S)-1-[3-hydroxy-2-(phosphonylmethoxy)propyl]cytosine. Mol Pharmacol 1992; 41: 197-202

228. Cihlar T, Votruba I, Horsk K, et al. Metabolism of 1-(S)-(3hydroxy-2-phosphonylmethoxypropyl)cyto-sine (HPMPC) in human embryonic lung cells. Collect Czech Chem Commun 1992; 57: 661-72

229. Neyts J, Sobis H, Snoeck R, et al. Efficacy of (S)-1-(3-hydroxy2-phosphonylmethoxypropyl)cytosine and 9-(1,3-dihydroxy2-propoxymethyl)guanine in the treatment of intracerebral murine cytomegalovirus infections in immunocompetent and immunodeficient mice. Eur J Clin Microbiol Infect Dis 1993; 12: $269-79$

230. Soike KF, Huang J-L, Zhang J-Y, et al. Evaluation of infrequent dosing regimens with (S)-1-[3-hydroxy-2-(phosphonylmethoxy)propyl]cytosine (S-HPMPC) on simian varicella infection in monkeys. Antiviral Res 1991; 16: 17-28

Correspondence and reprints: Dr Robert Snoeck, Rega Institute for Medical Research, Katholieke Universiteit Leuven, Minderbroedersstraat 10, B-3000 Leuven, Belgium. E-mail: robert.snoeck@rega.kuleuven.ac.be 